\title{
BERNARD SMITH, COLD WARRIOR
}

\section{Heather Barker and Charles Green}

\begin{abstract}
Bernard Smith's canonical book, Australian Painting 1788-1960, was shaped by the Cold War, and this forced the emerging discipline of Australian art history onto a trajectory that would not be shaken for another two decades. More than art history determined Smith's innovations. This paper proceeds from that obvious but easily overlooked point, that Smith and his book were deeply conditioned by the intellectual climate of Cold War Australia. The appearance of Smith's book and, henceforth, Australian art history's concerns with postcoloniality and anxiety about nationality derive from this. Smith's particular Cold War shaped Australian art history ever since.
\end{abstract}

Keywords: Bernard Smith $\bullet$ Australian art history $\bullet$ postcolonialism $\bullet$ cold war $\bullet$ criticism

\section{Introduction}

Bernard Smith's canonical book, Australian Painting 1788-1960 (Smith 1962), was shaped by the imprint of the Cold War, and this forced the emerging discipline of Australian art history onto a trajectory that would not be shaken for another two decades, a direction that continued in the 1980s' and then 1990s' emphasis on the ideologies of appropriation. This, more than art history determined Smith's innovations, though this is too-easily forgotten by a young, local art history anxious about more than influence. Anxious, instead, about its autonomy. This paper proceeds from that obvious but easily overlooked point, that Bernard Smith and his book, Australian Painting 1788-1960 were

\footnotetext{
(C) Copyright Charles Green and Heather Barker 2005

A version of this essay appeared as: Green, C. \& Barker, H. (2005). "Bernard Smith, Cold Warrior," Thesis 11, number 82 (August 2005), 38-53.

http://the.sagepub.com/cgi/content/abstract/82/1/38
} 
deeply conditioned by the intellectual climate of Cold War Australia. The appearance of Smith's book and, henceforth, the Australian art history discipline's concerns with postcoloniality and anxiety about nationality derive in no small part from this. The essay concludes that Smith's particular Cold War has shaped the terms of art history ever since. Later art critical developmentsincluding Australian theorisations about the two-way radial trajectory of postmodernism—were watermarked by the extra-artistic dynamic of the Cold War.

Art history in Europe and North America has changed since the height of the Cold War, when Australian Painting 1788-1960 appeared, and Australian art historians now normally take into account new feminisms, postcolonialisms and postmodernisms. All of these, we habitually suppose, postdate the intellectual climate of the early 1960s. A postcolonial perspective alone, though, is of questionable assistance in itself to understanding both writing and art that wishes to inscribe a truly global perspective onto the provincialism of both mainstream and regional art history, terms that were deeply inscribed by the Cold War.

In his gargantuan book, The Sociology of Philosophies: A Global Theory of Intellectual Change (Collins 1999), Randall Collins argues that the work of establishing new ideas is done in speech and writing directed at other people: in face-to-face argument, seminars, lectures, all the types of publication, letters, journal articles, texts.

The same is true of art: the work of new art and art criticism is carried on in discourse and in the exhibition of art as well as in the studio: in face-to-face argument, lectures, art magazines, catalogues, reviews, in patronage, art museum collections and in the performance and installation of art. This collides with the notion of the artist or the art writer as a wholly self-propelling, isolated figure, and with the notion of art history as driven by artistic innovation even if influenced in timbre and structure by its social context. 
We can further extend Collin's observations about philosophers to artists and art critics: artists and art writers alike have to establish themselves. In fact, they know that they have to learn how to take part in the art world, how to work out interesting positions and debates, and how to have their art or criticism capture attention. To succeed as an artist or an art writer is to secure attention; to fail is to find no-one to attack or praise you, even though it may take some time-even a decade or morefor attention to be excited.

The problem, however, with this line of reasoning is that art is not an argument, even if contemporary art has become more and more discursive to the point where a large proportion of well-meaning writers and artists valorise identity or celebrate its deconstruction. Art, though, is not necessarily a proposition, and images are not understood if they are exclusively interpreted as texts.

Finally, whether they are contemporary or long-dead historical figures, artists and art critics, like philosophers, have clustered in communities. Collins argues that, to be historically significant, a philosophical school must span two thirty-year generations. He also argues for the Law of Small Numbers, which holds that there can be no less than two and no more than six positions at any time, for without these numbers no self-sustaining intellectual community can flourish.

If we extend these suppositions to the history of Australian art and its criticism, small cities and isolated communities appear to be at severe disadvantages until we realize that artists and art writers, like philosophers, travel and correspond; they form alliances and affiliations outside the places they live. These are some of the considerations we might take into account in assessing the exemplary importance of Bernard Smith's work, rather than insisting on its singularity.

\section{Australian Painting 1788-1960}

Bernard Smith's friends and colleagues were the important and influential artists and writers of the post-World War II period, whose debates were conducted in the pages of journals and magazines such as Meanjin, Quadrant and Overland, which provide the explanatory wider context for Smith's 
book. The intellectual horizons of their collective work can be described by theories of the post- or neo-colonial condition. ${ }^{1}$ This, make no mistake, is the field of the Cold War.

Australian Painting 1788-1960, which appeared in that context, is without doubt the most influential single book thus far produced on Australian art. It is the seminal work of contemporary Australian art criticism as well as Australian art history in general — the first comprehensive, interpretative history written of Australian art. $^{2}$

It is effectively the platform on which Australian art history is built. Its success was deserved, for it was the result of long, thorough and inspired research by an excellent but partisan scholar who believed passionately in his project and who was a respected member of the academic art establishment, as small as that was at the time- - perhaps not more than five to ten people. This in itself was a significant ideological balancing act. Most importantly, the book discussed Australian art history up to the present, describing the growth of a local tradition that had matured to the point of having its own controversies such as the Dobell trial in Sydney and the Antipodean Manifesto in Melbourne. It was published at a time, 1962, when Australian society was gaining confidence in its abilities, welcoming works such as Australian Painting that legitimised Australian art through reference to respected European canons. We would say that Australian Painting took a postcolonial stance in the context of a neo-colonial society for which the colonising power had changed.

The book is a unique expression of Smith's interpretation of Australian art history stemming from his extensive scholarship and personal and public experience of living in Australian and English societies (Smith spent a significant period of time in bleak London during the immediate post-War period). Australian Painting's intellectual strands demonstrate all of the following: Smith's idiosyncratic Marxism, which emphasised the importance of social criticism in art; Smith's emphasis on art education; Smith's belief in the importance of Australian art as a recognised and recognisable national School; Smith's wish to shape, and be a player in, Australian art history. Each 
of these explains an aspect of the aims and discourse of Australian Painting. Smith's personal and public beliefs came together in this book. So, what community of ideas was it shaped by?

By the end of the 1950s, Australian intellectuals had recognised the national distinctiveness of Australian art and literature. Australian painters Sidney Nolan, Russell Drysdale, Albert Tucker and Arthur Boyd had attracted attention overseas, as had writers Patrick White and Ray Lawler. The first degree-level course in Australian literature was offered at Canberra University College in 1955. Art was considered to be part of the important national project of developing an Australian culture that emphasised Australia's difference from other countries but also firmly established its legitimacy within the dominant European canon. When Bernard Smith was appointed at the University of Melbourne in 1956, his main task in the Fine Arts department was to develop studies in Australian art history. He lectured in the second year course that covered eighteenth and nineteenth century European art and gave four or five lectures on Australian art towards the end of that course. He never wavered from that approach and wrote (Smith 2000, 7) in 2000, 'It was my view then, and is still my view now, that it is not possible to locate Australian art historically without some knowledge of the European art from which it derives.' Australian Painting was based on these lectures. He also supervised fourth year honours theses that usually researched Australian subjects for which primary source material was readily available.

The Cold War situation in Australia was never as restrictive as that generated by McCarthyism in the United States. Even though it is possible to categorise the local literary journals as 'leftist', 'middle ground' or 'right', the number of journals was too small to support an absolute separation of factions and there was an extensive cross-over of authors. Some writers such as Vincent Buckley and James McAuley published in Meanjin as well as Quadrant. James McAuley was a signatory to an open letter to the Commonwealth Literary Fund published in Overland (McAuley 1956, 5). The worth of individuals had to be judged by the quality of their work rather than the colour of the ink they used. It was acceptable to torment writers, artists and intellectuals, but they were too valuable, 
in part because so few, to Australian society to be discarded absolutely. However, cultural organisations were often believed to be fronts for communist activity and were regarded with suspicion. Writers and intellectuals often disseminated radical ideas that challenged the existing social order so they were liable to be judged dangerous. The Cold War exerted two powerful influences on the situation in which Australian Painting was written.

The first was the politics of the available outlets for art writing. Art criticism was fragmentary and unprofessionalised. Newspaper critics, then as now, did little more than review exhibitions, but there were no specialist or serious art journals or magazines published in Australia: Art in Australia had ceased publication in 1942 and Art and Australia did not begin publication until 1963. Artists' newsletters such as the Contemporary Art Society's Broadsheet were not political in the wider sense. Most of the considered discussion and debate about art was conducted in literary journals, in Meanjin, Quadrant and Overland.

The other powerful influence was the way funding was disbursed through the Commonwealth Literary Fund (CLF). The significant aspect of this funding was that there was a double approval system whereby the Advisory Board assessed the application on the basis of literary merit but the decision to fund or not to fund was made by the Political Committee. That is, the Advisory Board consistently asserted the literary content of journals as a criterion for funding but ultimate approval was given by the Political Committee whose criteria included both the literary and the political. In 1952, for example, Prime Minister Menzies ordered that the Australian Security Intelligence Organisation (ASIO) vet all CLF applicants. He had learned that Judah Waten, a Communist although not then a member of the Party, had been awarded a grant. Menzies' directive gave ASIO real power to categorise left-wing applicants as security risks who were therefore ineligible for funding. The Whitlam Government's introduction of Australia Council funding direct to artists, writers and journals, assessed by panels of peers though an arms-length mechanism similar to that of refereed journals in academe, changed all this. 
Meanjin received its first grant from the Commonwealth Literary Fund in 1946. The grant was suspended in 1948 and 1949. Critics of the journal contended that by engaging in political comment the editor disqualified it from receiving assistance as a literary magazine - the Political Committee objected to editorials about elections in Europe and Australia. ${ }^{4}$ The federal government cancelled its large Meanjin order in 1950 but CLF funding was granted. Throughout the 1950s Meanjin maintained its interest in literature, art and theatre and battled to maintain its non-aligned policy of printing material from both sides of politics. In the polarised climate of the Cold War, though, Christesen's chosen middle ground became a no-man's land.

An important Cold War belief about communism was that it was an invisible force, a spectre hiding behind a façade of respectability. In the mid-1950s, 'the spectre of Communism was made flesh' (Capp 1993, 136) when the Royal Commission on Espionage was conducted in 1954-5. The Commission was called following the defections of Vladimir and Evdokia Petrov from the Soviet Embassy in Canberra. Among the witnesses subpoenaed to appear were Clem and Nina Christesen who had been named as contacts in Petrov's papers. Although Christesen had never been a member of the Party, his wife, Nina, was Russian—regarded as a political act in itself—and he persisted with the Meanjin editorial policy of printing material from all sides of the political debate. Add his support for the peace movement and there was sufficient cause to identify him and his journal as instruments of subversion (McLaren 1996). The Christesens were cleared of any association with spying or treason — no evidence at all of espionage was found by the Commission — but the 'taint of association' remained (Strahan and Wallace-Crabbe 1981, 176).

Throughout the 1930s, 1940s and 1950s, The Communist Review, Realist Writer and Overland dealt with the issue of Australian realism, taking it as the ultimate and central criterion of artistic value. It was crucial for the left to retain the traditional bush-socialist nexus that had appeared so convincing during the 1920s and 1930s. The revolutionary cause had been aligned with the nationalist cause. The theory of socialist realism enabled socialist and Communist intellectuals to develop a notion of 
a continuous tradition of Australian realism from the end of the nineteenth century. During the 1940s and 1950s, however, the ideological differences that split the Communist Party also widened the gap between socialist realism and realism. Bernard Smith cited his opposition to Cold War socialist realism as one of his reasons for leaving the Party.

The Realist Writer had been founded in 1952 as the bulletin of the Realist Writers' Group. In 1954, Judah Waten obtained funds to turn the bulletin into a printed magazine that was called Overland (Murray-Smith, 1998, 186). Overland, in Murray-Smith's words, 'set out to talk of books and writing in an unselfconscious way with the assumption that there was no reason whatsoever why 'ordinary people' should not enjoy such writing and participate in it' (Murray-Smith 1998, 186). The magazine aimed to publish writing that was meaningful because it dealt with 'our local reality', not because it was necessarily the best writing (Murray-Smith 1998, 187). The concern with class was a dominating feature of Overland. The magazine was aimed at working class readers, by whom it was strongly supported. Essays were chosen for inclusion on the basis of social realism, not avant-garde literary standards. Even so, the journal's commitment to socialist realism never degenerated into the sectarian exclusion of work that failed to satisfy the current thinking of Party leaders and, in 1958, Ian Turner and Stephen Murray-Smith abducted Overland, taking it away from the writers' faction of the Party. Overland was located at one of the binary poles of the leftright discourse: the profound left.

Overland's editor, Stephen Murray-Smith, began applying for CLF funds in 1955 but his applications were unsuccessful until a grant to cover the journal's accumulated deficit was made in 1963. From 1964 only, Overland was given an annual grant of $£ 250$, the same amount and on the same basis as Quadrant. Prime Minister Menzies had consistently overridden the Advisory Board recommendation to fund Overland, which he did not consider to be a reputable literary magazine because, he claimed, its standards were lower than other journals. Nation reported this refusal to 
fund Overland in an article entitled 'Mr Menzies Reads Overland'. Its author, K.D. Gott (Gott 1961, 6) concluded:

Mr Menzies will either have to assume the role of one who has more discernment than the Board in literary matters, using pomp to justify pettiness, or else brazen the thing out as a plain piece of political discrimination. After all, he has the manner to adopt the first course, and the numbers to take the second.

Clearly, the refusal to fund Overland was publicly noted and commented upon. This did not however, change the decision or influence the next funding round. In July 1962, Gott reported that the CLF again refused a subsidy to Overland. In this article, Gott (Gott 1962, 7) notes that in 1957 Murray-Smith was told that his three-year-old magazine had not been established long enough to prove itself. In 1961, he was given no reason for the refusal of a grant. In 1962, the issue was 'clouded with suggestions of insufficient literary merit.' Later in the article, Gott declares that the 'discrimination against Overland is more clear than ever.'

Quadrant began publication in 1956. It sat at the other pole of the left-right binary. The journal's key figures were intellectuals of the conservative tradition: Quadrant's editor (1956-73) James McAuley, A.D. Hope, Vincent Buckley and Leonie Kramer. In the first issue, McAuley(McAuley $1956,5)$ announced that the journal would oppose what he called the 'anti-intellectual criterion' of 'Australianity'. His opposition to 'Australianity' was twofold: he believed that all writing should be measured against literary standards that transcended nationality (although they were set by the English literary canon); and he regarded the use of national standards as Communist (as represented by Overland and Meanjin). McAuley's second bete-noir was the 'decayed avant-garde mentality' of artistic modernism. He saw the subjectivism and experimentation of modern art as symptomatic of the erosion of social custom and tradition by western liberalism. This degeneration put western societies at serious risk of destruction at the hands of Communism. 
Buckley and Kramer were particularly influenced by F.R. Leavis's critical method, which evaluated work against absolute the literary standards demonstrated by a highly selective literary canon. The major impact of Leavisite critical practice was felt through the application of literary quality and the search for universal, not local values in Australian literature. Buckley and Kramer attacked literary nationalism, particularly the 'literary double standard' which Kramer (Kramer 1985, 295) has called the 'inclination to deal with local writers tenderly.' They sensed that nation was the means for the left to sublimate their radicalism and preferred to elide nation in favour of the canon. This was an astute judgment, and we would assert its persistence in art long afterwards, even in inverted forms once postmodern theory arrived, and in Smith's book. This sublimation should be held in mind as we develop the argument.

Quadrant was funded by the Congress for Cultural Freedom (CCF) through its affiliate, the Australian Association of Cultural Freedom (AACF). The CCF was set up in Berlin in 1950 under the patronage of Bertrand Russell, Benedetto Croce, John Dewey, Karl Jaspers and Jacques Maritain. Its aim was to be an organisational base for the defence of freedoms, liberties and creativity. Communism was seen as the main threat. Magazines or journals such as Encounter in England and Preuves in France were founded through its affiliated organisations. Richard Krygier, Secretary of the ACCF, initiated a proposal for a quarterly magazine in Australia. He wanted the new journal to counter the influence of Meanjin for that journal, he noted in a letter to the CCF in 1942, was published by the University of Melbourne, 'which does not mean that it is not a rabidly pro-Communist magazine' (McLaren 1996, 28). The CCF International Executive in Paris endorsed the proposal in January 1956. Outside funding gave Quadrant permanence and continuity. McAuley, unlike Christesen at Meanjin, did not have to spend time and energy looking for, and servicing, sponsorship. Richard Krygier began applying for CLF funding for Quadrant in 1957. His applications were refused on the grounds of too little literary content until 1960 when the journal was granted $£ 250$. It was later revealed that the CCF, and therefore, Quadrant, was partially funded 
by the CIA but this did not cause the furore that surrounded any revelation of Communist Party funding.

\section{Bernard Smith and the Cold War}

Smith felt the chill of the Cold War when he returned from London in 1949 and found his job at the Art Gallery of New South Wales only saved by the intervention of Mary Alice and 'Doc' Evatt. ${ }^{5}$ Things got worse. During the 1940s and early 1950s, security files were kept on thousands of Australians, including 63 staff members of the University of Melbourne. There were four categories along a continuum that moved from Communist Party members (A), through suspected members (B) and sympathisers (C) to advocates of 'free thought' (D). Two thirds of those under surveillance were in category D, including Zelman Cowen, Professor of Law and future Governor General (Capp 1993, 91-93). By the time Smith took up his position in the Fine Arts Department of Melbourne University, Cold War anti-communism was at its most virulent. The Petrov Royal Commission had all but destroyed Evatt's political career and the Australian Labour Party had split over the issue of Communism. Further, Joseph Burke, Professor of Fine Arts, had fallen out with Clem Christesen and Meanjin in 1948 over the publication of Eric Dark's article (Dark 1948) 'Political Bias of the Press.' Burke (Strahan 1984, 124) wrote to Meanjin's editor, Christesen, declaring: 'Meanjin ought to expose Soviet Communism as the chief danger to intellectual freedom that exists in our age and society. ${ }^{6}$ The correspondence between Burke and Christesen arising from this dispute continued until 1960. Smith was known to have radical, left wing sympathies and his Communist past was common knowledge; Burke was extremely circumspect about the public expression of political sympathies though he referred to himself as a liberal with a small-“l”. The two mixed socially but were not necessarily personally close. Smith could clearly not have taken clear public stances in support of the left without seriously affecting his new position at Melbourne University and attracting the damaging attention of the anti-communist crusaders of the right. He had to be careful that his reputation as an academic art historian was strong enough to outweigh his 
ambivalent status as an ex-member of the Communist Party and associate of Mary Alice and 'Doc' Evatt. He published five articles in Meanjin between 1951 and 1953, one in 1956, one in 1957, and one in 1959. ${ }^{7}$ Once Smith was tenured, his employment was as secure as his public position and his place in history was not. In 1987, Dorothy Hewett (Hewett 1987, 66) succinctly recalled this climate when she wrote: 'The thirties created us, McCarthy made us immortal, The Cold war embalmed us.' The power of Cold War events to enflame passion and argument has faded but not disappeared.

\section{Australian Painting as Postcolonial Discourse}

Settler societies are frequently constructed, as postcolonial theorists have variously argued, within a discourse of difference and inferiority by the colonising power. So settler societies suffer the discrimination of colonial subjects themselves. If we take postcolonial theory as the methodology that best explains the 'form of talk' (Ashcroft, Griffiths and Tiffin 1989, 211) within the white settler colony (even, by 1960, a neo-colony), we can begin to understand not just the place and formation of Smith's work, but also its intellectual project. If Australian Painting describes the process of forging a distinctive and unique culture in Australian painting up to the time it was recognised by Australian commentators, that is, the Heidelberg School in art and the bush legend in literature, then this project itself exerted an ideological agency governed by sublimation in a manner that the two-way influences mapped so innovatively in European Vision, and even tentatively delineated at the conclusion of Place, Taste and Tradition, escapes. The impact on the centre that forces the centre to redefine itself (or, in Place, Taste and Tradition, which should make it redefine itself) is less marked in Australian Painting. Australian Painting is a Cold War book, just as Place, Taste and Tradition is a wartime book. The Australian identity that Australian Painting traced had been strengthened by the experience of the First World War and the experiences of the Depression, but fossilised by Russel Ward's The Australian Legend. It is clear that much material written in the 1950s — not just Australian Painting — stresses again and again the necessity of developing an 
Australian identity through literature and art, in order to define what that identity should be by recording its observations and analysis of the necessarily emerging and hopefully distinctive Australian culture. Australian Painting was written in this intellectual context, even though we see that Australian context as that of a white settler colony occupying the ambivalent position of both colonised and coloniser. The present discussion will confine itself to the context of the Australian white settler colony that had been colonised by the British colonising power rather than the society that colonised its indigenous population; this is a subject that refuses cursory treatment and is in any case now the more usual subject of postcolonial art criticism. The settler colony's situation is well expressed by Ashcroft, Griffiths and Tiffin in Key Concepts in Post-Colonial Studies (Ashcroft, Griffiths and Tiffin 1989, 211):

Settlers are displaced from their own point of origin and may have difficulties in establishing their identities in the new place. They are frequently constructed within a discourse of difference and inferiority by the colonising power ('colonials/colonial') and so suffer discrimination as colonial subjects themselves.

It is not hard to find examples of Australian 'colonials' who experienced this treatment, in Australia and in England. Andrew Riemer talks about it in Sandstone Gothic. Bernard Smith talks about it in A Pavane for Another Time. An excellent expression of the discourse of inferiority can be found in Noel Barber's Conversations with Painters (Jeannerat 1964). Each of the conversations with artists in this book is preceded by a short section written by Daily Mail critic Pierre Jeannerat. The conversations with 'British' artists include one with painter Sidney Nolan. Jeannerat's introduction to Nolan contains some gems of dated wisdom that illustrate the startling European neo-colonial paternalism that was presumably heightened by his experiences in India. While setting the scene of Australia as a remote and exotic place, he tells the reader (Jeannerat 1964, 85) that 'Aborigines, most uninventive of all living men, actually fling a curved shooting stick that conveniently returns if it misses its mark,' apparently without seeing any inconsistency in his comment. As he turns his 
attention to Australian painting he notes (Jeannerat 1964, 85) the early failure of artists to capture anything exciting when he writes, 'Transplanted European art has for the most part been disappointingly tame under distant skies.' In keeping with the growing sense of a maturing Australian identity, he asserts (Jeannerat 1964, 86) that 'Australian painting has found wings in a number of young artists who proclaim clearly the oddity and uniqueness of their continent, antipodean to us in Great Britain.'

Australia had never become truly independent of Britain, but World War II had precipitated a shift in dependency — the US now became Australia's great and powerful friend. American capitalism threatened the brave egalitarian world that the Left planned for post-war Australia, although that dream was pretty well dead after the Cold War, the invasion of Hungary and the Petrov affair. As Smith (Smith 1962, 326-333) noted, American culture threatened any emerging Australian distinctiveness, and American abstraction threatened to overwhelm the weakened but revered European artistic tradition of humanist art based on the depiction of the human figure. ${ }^{8}$ The process of establishing an independent cultural identity in the face of both traditional and newly powerful influences was obviously crucial. We could predict — this is familiar postcolonial territory — that the first cultural task would be to record a body of work separate from that of the colonising centre, to compile a national history that consequently posited semi-autonomous national cultural lineages. This is precisely what Bernard Smith's powerful, quasi-Biblical but, most crucially, academically formulated narrative of Australian painting does. It converts anecdote and art criticism into a closely argued, cyclic teleology that subsequent scholars could take issue with, embellish or embroider. Helen Tiffin (Tiffin 1995, 95) wrote, 'Decolonisation is process, not arrival; it invokes ongoing dialectic between hegemonic centrist systems and peripheral subversion of them.' Smith's account is dialectical, dominated by the stresses and counter-stresses of radial influence, and cyclic. How did this process unfold? In Australia after the Second World War and until the early 1960s, critics of the liberal and left traditions supported the development of identifiably Australian art and 
literature. They emphasised its distinctiveness and strength. British and US hegemony was rejected and emphasis was placed on a national art and literature, but the theoretical assumptions, critical perspectives and value judgements remained those of the British, ex-colonial, and now neo-colonial establishment.

It can be argued that, although Smith denies that nationalism was his motivation (and more recently he has reclaimed internationalism and globalisation as his cultural project) his opposition to abstraction was also an opposition to US hegemony. When he supported Australian art, he did so from the critical perspective of the British and European art history establishment; his otherwise inexplicable aesthetic preferences for some painters above others certainly bear this out. Bernard Smith published three books in the period that established paradigms for the interpretation of Australian art, albeit in European art historical terms. European Vision and the South Pacific argued that the experience of the Antipodes changed the way that European artists saw and represented the world and that, eventually, the experience of the Antipodes changed European ideas about the world and its order. In turn, Smith fully expected that contemporary Australian art would invigorate British art. He believed that the way to secure recognition in Britain and Europe of Australian art was to demonstrate that its strength and vitality could revitalise the jaded art that was being produced and was under threat from American abstract expressionism. In 1959, he lobbied Herbert Read and Kenneth Clark (Smith 1986) for their support in arranging an exhibition of Australian painting in London with the argument that the strength of Australian painters such as Nolan would revitalise British art. He explained to Bryan Robertson of the Whitechapel Gallery in London, that the Antipodeans saw themselves as 'defenders and indeed champions of the image' and that they offered fresh formal insights and new ideas that had the potential to rescue Britain's modernist tradition of figuration from the advance of American abstract expressionism (Whitehouse 1999, 296). ${ }^{9}$ 
In postcolonial terms, marginality had become 'an unprecedented source of creative energy' (Ashcroft, Griffiths and Tiffin 1989, 133). The centre moved to subsume, incorporate and reify its successful colonial art and literature. The work was approved according to conservative Eurocentric standards and claimed as British. By the time Australian Painting was published (1962), four of the seven Antipodean artists were living in England or Europe (Charles Blackman, Arthur Boyd, David Boyd and John Perceval), joining Sidney Nolan who had been based in London since winning the Dunlop Prize in 1950. This had happened to artists before the Antipodeans, to some of the Antipodeans themselves, and to artists such as Peter Booth since, who was identified as a British artist affiliated with English neoexpressionist painters by the Metropolitan Museum of Art in New York when that institution displayed his work in its permanent collection rehang in the late 1980s. Writing in 2000, Smith comments that 'Arthur Boyd, Charles Blackman, Clifton Pugh, and John Perceval were off to Britain to win greater fame abroad' (Smith 2000, 8). But what really happened was that Sidney Nolan, Russell Drysdale, Albert Tucker, Arthur Boyd became expatriate Australian artists and part of the conservative British art establishment, an art establishment whose painters were of little lasting importance in the larger scheme of things. The artists who had been shining stars of the new national School lost nationalist credibility as they became part of the British aristocracy. But Britain itself had long been an artistic backwater, and was itself now a provincial cultural scene relative to New York. Its own local avant-garde painter-heroes of the period, artists such as Peter Lanyon, Alan Davie and Patrick Heron, were intensely aware of this relegation.

\section{Conclusion}

Smith was still fighting his losing battle against abstraction in 1962, but the centre had already shifted. His Antipodeans sold out to the British establishment, the Cold War crushed the Australian left, and imperial America now occupied centre stage. The process continued but with new people, new imperatives and a new centre-New York - that attracted the next generation of art historians and critics such as Patrick McCaughey and Terry Smith. 
We have argued that Bernard Smith and his work might begin to be interpreted as part of the intellectual climate of neo-colonial Cold War Australia. European Vision and the South Pacific was researched during his time in London and is marked by the international context of the 1940s and 1950s. It is the coda for the impact of the Antipodes on Europe that he had traced in European Vision, a very different book of lasting intellectual importance. Australian Painting, 1788-1960 is about a national school of Australian art developing under influence radiating from the centre. It is not simply possible, but necessary if we are to assess Smith's place in history, to take a step back and interpret his writing not just in terms of its broad and impressive scholarship, but also in terms of its membership of intellectual communities, in terms of its place in time, as a product of the Cold War.

Heather Barker is a $\mathrm{PhD}$ candidate at the University of Melbourne. Her academic background is in History and Asian Studies and she brings skills and perspectives developed there to her current research area of Australian art critical writing, 1960-1988 (email:

h.barker2@pgrad.unimelb.edu.au).

Charles Green is Senior Lecturer in Contemporary International and Australian Art, in the School of Art History, Cinema, Classical Studies and Archaeology at the University of Melbourne, and Senior Adjunct Curator of 20th and 21st Century Art, National Gallery of Victoria. He has published Peripheral Vision: Contemporary Australian Art 1970-94 (Sydney: Craftsman House, 1995), and The Third Hand: Artist Collaborations from Conceptualism to Postmodernism (Minneapolis: University of Minnesota Press, 2001). He is an artist working in collaboration with Lyndell Brown. Recently, he has co-curated world rush_4 artists: Doug Aitken, Eija-Liisa Ahtila, Lee Bul and Sarah Sze (Melbourne: National Gallery of Victoria International, 2003), Fieldwork: Australian Art 1968-2002 (Melbourne: National Gallery of Victoria Australia, 2002); and 2004 (Melbourne: National Gallery of Victoria and ACMI, 2004) (email: c.green@unimelb.edu.au). 


\section{References}

Ashcroft, Bill (1996) 'On the Hyphen in "Post-Colonial"‘, New Literature Review. 32 (Winter 1996), 23-31.

Ashcroft, Bill, Griffiths, Gareth, Tiffin, Helen (1989) The Empire Writes Back: Theory and Practice in Post-Colonial Literatures, Routledge, London.

Brack, John (1962) ‘Critic or Historian’, Australian Book Review, December 1962. 26.

Buckridge, Patrick (1998) 'Clearing a Space for Australian Literature 1940-1965,' in The Oxford Literary History of Australia, edited by Bruce Bennett, Jennifer Strauss and Chris WallaceCrabbe. Oxford University Press, Melbourne. 169-193.

Capp, Fiona (1993) Writers Defiled: Security Surveillance of Australian Authors and Intellectuals 1920-1960. McPhee Gribble, Ringwood.

Collins, Randall, (1999) The Sociology of Philosophies: A Global Theory of Intellectual Change. Harvard University Press, Cambridge, Mass..

Dark, Eric (1948) 'Political Bias of the Press', Meanjin, 7 (1), Autumn 1948. 23-9.

Gott, K.D. (1961) 'Mr Menzies Reads Overland', Nation, 3 June 1961. 6.

Gott, K.D. (1962) 'Overland's Demerit', Nation, 28 July 1962. 7.

Hewett, Dorothy (1987) Alice in Wormland. Paperbark Press, Paddington.

Jeannerat, Pierre (1964) 'Sidney Nolan', in Conversations with Painters, edited by Noel Barber. Collins, London. 85-8.

Kramer, Leonie (1985) 'The Media, Society and Culture', in Australia: The Daedalus Symposium, edited by S.R. Graubard. Angus \& Robertson, Sydney.

Lynn, Elwyn (1963) ‘A History of Australian Painting: II 1939-1960’ Meanjin, 23 (June 1963). 229-35.

McAuley, James (1956) 'Editorial,' Quadrant. 1 (1), June 1956. 5.

McLaren, John (1996) Writing in Hope and Fear: Literature as Politics in Post-War Australia. Cambridge University Press, Melbourne.

Murray-Smith, (1998) Stephen 'Overland' in Cross Currents: Magazines and Newspapers in Australian Literature, edited by Bruce Bennett. Longman Cheshire, Melbourne. 183-91.

Smith, Bernard (1962) Australian Painting 1788-1960. Oxford University Press, Melbourne.

Smith, Bernard (1986) 'Foreword', in Fuller 1986: Fuller, Peter, The Australian Scapegoat: Towards an Antipodean Aesthetic. University of Western Australia Press, Nedlands. 
Smith, Bernard (2000) 'Introduction: A Bibliographical Memoir', in The Writings of Bernard Smith: Bibliography 1938-1998, edited by John Spencer and Peter Wright. Power Publications, Sydney, 2000. 3-14.

Strahan, Lynne (1984) Just City and the Mirrors: Meanjin Quarterly and the Intellectual Front, 1940-1965, Oxford University Press, Melbourne.

Strahan, Lynne and Wallace-Crabbe, Chris (1981) 'Meanjin Quarterly' in Cross Currents: Magazines and Newspapers in Australian Literature, edited by Bruce Bennett. Longman Cheshire, Melbourne. 172-82.

Tiffin, Helen (1995) 'Post-colonial Literatures and Counter-discourse', in The Post-colonial Studies Reader, edited by Bill Ashcroft, Gareth Griffiths and Helen Tiffin. Routledge, London. 95-98.

Westbrook, Eric (1963) ‘Australian Painting', Overland, 26 (April 1963). 31-32.

Whitehouse, Denise (1999) The contemporary art society of NSW and the theory and production of contemporary abstraction in Australia 1947-1961. Unpublished PhD thesis, Monash University, Melbourne.

\footnotetext{
${ }^{1}$ The punctuation of the word 'postcolonial' is itself much contested. Should it be hyphenated or unhyphenated? Bill Ashcroft (Ashcroft 1996) argues for the hyphenated form, concluding that the hyphen 'signifies difference, resistance, opposition'. We use the nonhyphenated form and carefully distinguish between two uses of the term 'postcolonial'. One usage is to define a cultural condition arising after the colonial period, as in 'post-colonial Australia'. The other usage is to designate a corpus of sophisticated theory analysing this condition. We also note that Ashcroft defines the term in a much broader sense: 'The post-colonial is not a chronological period but an historical condition, a way of contending with various specific forms of colonial oppression'. Also see Ashcroft, Griffiths and Tiffin 1989; this is the principal reference used in this paper as it is an excellent starting point for a discussion of postcolonial writing. However, the debate about settler colonies and postcolonial writing has advanced considerably since 1989.

${ }^{2}$ The boundaries and categories established in Smith's book are still observed. The second edition was published in 1971 with four new chapters. The third edition was published in 1991 with three additional chapters by Terry Smith. The fourth edition with an additional section by Christopher Heathcote was published in 2001

${ }^{3}$ G.A. Wilkes was appointed Foundation Professor of Australian Literature at the University of Sydney in 1962 with funding $(£ 80,000)$ raised by a public appeal. For further discussion of this topic see Patrick Buckridge, 'Clearing a Space for Australian Literature 1940-1965' in Bruce Bennett, Jennifer Strauss and Chris Wallace-Crabbe (eds), The Oxford Literary History of Australia, Melbourne: Oxford University Press, 1998, 169-193.

${ }^{4}$ Tom Inglis Moore advised that Meanjin keep the 'purely literary content to more than half, and always higher than Quadrant's' (Moore's emphasis) in a letter to Geoffrey Serle and thence to Christesen, cited in McLaren 1996, 122.

${ }^{5}$ Late in 1950, Evatt accepted a brief to represent the communist-controlled Waterside Workers' Federation in the High Court challenge to the Communist Party Dissolution Act that had been signed into law on 19 October 1950. In June 1951, Leader of the Opposition Ben Chifley died and Evatt succeeded him as Leader of the Federal Parliamentary Labor Party. Evatt was victorious over Menzies in the High Court action and
} 
in the subsequent constitutional referendum. Menzies, however, was able to turn defeat into victory by arguing that the Government had done everything it could do to meet the threat of Communism but that its attempts had been thwarted by the Australian Labor Party and its leader, Doctor Evatt. The Royal Commission into Espionage that followed the defection of Vladimir Petrov was the final blow to Evatt's political career. Petrov claimed that he could provide evidence that an espionage ring was operating in Australia and that members of Evatt's staff were implicated. Evatt intervened on behalf of his staff but after repeated clashes with witnesses and Commissioners was denied further permission to appear. Evatt retired from politics in 1960.

${ }^{6}$ Letter by Joseph Burke to Christesen, 25 October 1949, cited in Strahan 1984, 124.

7 'Fifty Years of Painting in Australia' Meanjin, 10 (4), Summer 1951, 354-8; 'Art Chronicle, Australian Expressionism', Meanjin, 11 (3), Spring 1952, 256-8; 'Art in the Dog-days', Meanjin, 12 (1), Autumn 1953, 55-8; 'The French Art Exhibition', Meanjin, 12 (2), Winter 1953, 165-74; 'Archibald, Wynne and Sulman Awards for 1953', Meanjin, 13 (1), Autumn 1954, 106-8; 'John Russell: Australia's Unknown Artist', Meanjin, 15 (4), Summer 1956, 352-6; 'Notes on the Life and Art of Charles Doutney', Meanjin, 16 (4), Summer 1957, 420-4; 'Evolution and Australian Nature', Meanjin, 18 (1), Autumn 1959, 83-7.

${ }^{8}$ The last section of the last chapter of Australian Painting is entitled 'The Melbourne Reaction against Abstraction (326-333). Three pages (328-330) are devoted to the Antipodeans and the Antipodean Manifesto, including one page (329) of extensive quotes. By 1962, the Antipodean Manifesto (1959) was old news. But Smith revived the issues by including it in the final chapter of Australian Painting. Why? What prompted his continuing determination to keep the Manifesto in view? Smith's belief in art as a dialectical critique of society partly explains his determined views against abstraction, particularly American abstract expressionism. Interestingly, Smith declared his involvement with the Manifesto only in a endnote to the text of the Australian Painting (Endnote 30 on page 333). The endnote occurs in the middle of a paragraph about the Antipodeans that pointedly avoids any mention of Smith's part in the production of the Manifesto. Reviewers of Australian Painting, however, knew how deeply Smith was involved. In his review (Brack 1962, 26) of the book, John Brack, himself an Antipodean, asks 'Who will claim detachment about his contemporaries? As a matter of fact it is apparent that here Dr Smith is very much engagé, with no apologies to anyone' Eric Westbrook (Westbrook 1963, 31-32), reviewing Australian Painting in Overland, commented, 'Art history is best written from the outside, for the world looks very odd from the belly of the whale, and we are still little Jonahs attempting an assessment of the real value of the short-lived Antipodeans'. In Meanjin, Elwyn Lynn (Lynn 1963, 231) commented, however, that ' $\mathrm{t}$ ]hose who believe in the Principle of Terminal Decades wish the book had stopped at 1950'.

${ }^{9}$ Letter from Bernard Smith to Bryan Robertson, 4 April, 1959, requesting an exhibition at the Whitechapel Gallery in Spring 1960, Smith's personal papers, cited in Whitehouse 1999, 296. 


\section{University Library}

\section{- M M N E R VA A gateway to Melbourne's research publications}

Minerva Access is the Institutional Repository of The University of Melbourne

Author/s:

BARKER, H.;Green, C.

Title:

Bernard Smith, cold warrior

Date:

2005

Citation:

Barker, H., \& Green, C. (2005). Bernard Smith, cold warrior. Thesis eleven, 82(1), 38-53.

Publication Status:

Published

Persistent Link:

http://hdl.handle.net/11343/34697 